\title{
MICROSCOPIC CHARACTERIZATION AND PARTICLE DISTRIBUTION IN A CAST STEEL MATRIX COMPOSITE
}

\author{
MIKROSKOPSKA KARAKTERIZACIJA IN RAZPOREDITEV \\ DELCEV V KOMPOZITU Z MATRICO LITEGA JEKLA
}

\author{
Ana Kračun ${ }^{1,2}$, Matjaž Torkar1, Jaka Burja1, Bojan Podgornik ${ }^{1}$ \\ ${ }^{1}$ Institute of Metals and Technology, Lepi pot 11, 1000 Ljubljana, Slovenia \\ 2International postgraduate school Jožef Stefan, 1000 Ljubljana, Slovenia \\ ana.kracun@imt.si \\ Prejem rokopisa - received: 2015-10-01; sprejem za objavo - accepted for publication: 2015-12-24
}

doi:10.17222/mit.2015.310

\begin{abstract}
The purpose of this investigation was to identify the distribution of ultrafine particles in a steel matrix introduced through a conventional melting and casting method, and above all to determine the methodology and analysing techniques suitable for the analysis and identification of ultrafine particles incorporated into the steel matrix. In the frame of this work, steels dispersed with $\mathrm{Al}_{2} \mathrm{O}_{3}$ ultrafine particles were produced by a conventional casting method and their microstructure investigated with light microscopy (LM), scanning electron microscopy (SEM) and auger electron spectroscopy (AES). Microstructural analyses show that the distribution of the $\mathrm{Al}_{2} \mathrm{O}_{3}$ ultrafine particles is non-uniform and has a high degree of agglomeration. Furthermore, for a detailed analysis of the nanoparticles a specific preparation and characterization using advanced microscopic techniques is required.
\end{abstract}

Keywords: particle distribution, microscopic characterization, steel matrix

Namen raziskave je bil ugotoviti porazdelitev ultrafinih delcev v jekleni matrici, ki je bila proizvedena s konvencionalnim postopkom litja, predvsem pa določiti metodologijo in analizne tehnike, primerne za analizo in identifikacijo ultrafinih delcev, ki so bili vključeni v jekleno matrico. Delci $\mathrm{Al}_{2} \mathrm{O}_{3}$ so bili dodani med procesom konvencionalnega litja in so bili analizirani s pomočjo različnih analiznih tehnik, in sicer: z uporabo optičnega mikroskopa (LM), vrstičnega elektronskega mikroskopa (SEM) in spekroskopije Augerjevih elektronov (AES). Analiza mikrostrukture je pokazala neenakomerno porazdelitev in aglomeracijo $\mathrm{Al}_{2} \mathrm{O}_{3}$ delcev. Za podrobno analizo je potrebna karakterizacija mikrostrukture s pomočjo naprednih mikroskopskih tehnik.

Ključne besede: porazdelitev delcev, mikroskopska karakterizacija, jeklena matrica

\section{INTRODUCTION}

The insertion of ceramic reinforcements into metal matrices to produce composite materials with improved properties has been a subject of intensive research during the past three decades. ${ }^{1-3}$ Ceramic particulates such as borides, carbides, oxides and nitrides are added to metal matrix composites (MMCs) to improve their elastic modulus, wear resistance, creep and strength..$^{4-5}$

The ductility of MMCs, however, deteriorates at high ceramic particle concentrations ${ }^{5}$. The metal matrix, the so-called metal-matrix nano-composite (MMnCs) is strengthened by nano-sized ceramic particles. ${ }^{6}$ These nanoparticle reinforcements can significantly increase the mechanical strength of the metal matrix, as they promote particle hardening more effectively than micro particles. Moreover, MMnCs improve the performance significantly at elevated temperatures, because the ceramic nanoparticles can maintain their properties at high temperatures. ${ }^{6}$

Steel matrix composites commonly have a combination of hard ceramic (e.g., TiC, $\mathrm{TiB}_{2}, \mathrm{WC}$ and $\mathrm{Al}_{2} \mathrm{O}_{3}$ ) reinforcements and a ductile metallic matrix, which makes them promising candidates for high-strength and wear-resistance applications. There are several methods for fabricating particulate-reinforced steel matrix composites, such as powder metallurgy, conventional melting and casting, reactive sintering and self-propagating high-temperature synthesis (SHS). The casting process is simple and more economical than the other available routes for integrating nanoparticles into the microstructure of steel. However, it is extremely difficult to obtain a uniform dispersion of ceramic nanoparticles in liquid metals due to the poor wettability and the difference in the specific gravity between the ceramic particles and the metal matrix. ${ }^{7}$

The microstructure of metals is generally characterized by advanced microscopic techniques (e.g., LM, SEM and TEM) which probe and map the surface and sub-surface structure of a material. These techniques can use photons, electrons, ions or physical cantilever probes to gather data about a sample's structure on a wide range of length scales. ${ }^{8}$ Auger electron spectroscopy (AES) also provides quantitative elemental information from the surfaces of solid materials. ${ }^{9}$

The current work aims at contributing to the knowledge and understanding of the conventional casting route for ultrafine particle inoculation in a steel matrix. This 
production route seems to show potential and offers more cost efficiency in achieving the dispersion of second-phase ultrafine particles compared to the powder and metallurgical techniques used until now. The aim of the work was therefore to study the influence of $\mathrm{Al}_{2} \mathrm{O}_{3}$ ultrafine particles on the microstructure of a steel matrix using a conventional casting method. The additional aim is to determine the methodology and analysing techniques suitable for analysing and necessary to identify the ultrafine particles incorporated in the steel matrix.

\section{EXPERIMENTAL WORK}

\subsection{Material}

Austenitic stainless steel was used for the work, mainly due to the distinctive two-phase microstructure of austenite and ferrite. The chemical composition of this alloy is given in Table 1. These are the most used group of stainless steels. They are paramagnetic, have a facecentred cubic lattice and excel with a good combination of hot and cold workability, mechanical properties and corrosion resistance.

Table 1: Chemical composition of austenitic stainless steel in mass fractions, $(w / \%)$

Tabela 1: Kemijska sestava avstenitnega nerjavnega jekla v masnih deležih, $(w / \%)$

\begin{tabular}{|c|c|}
\hline Elements & $w / \%$ \\
\hline $\mathrm{C}$ & 0.02 \\
\hline $\mathrm{Si}$ & 0.33 \\
\hline $\mathrm{Mn}$ & 1.24 \\
\hline $\mathrm{Cr}$ & 17.4 \\
\hline $\mathrm{Ni}$ & 10.1 \\
\hline $\mathrm{Cu}$ & 0.36 \\
\hline $\mathrm{Mo}$ & 1.29 \\
\hline $\mathrm{V}$ & 0.08 \\
\hline
\end{tabular}

As the reinforcement particles, commercial ultrafine $\mathrm{Al}_{2} \mathrm{O}_{3}$ powder with a mean particle size of $500 \mathrm{~nm}$ was used, as shown in Figure 1. The $\mathrm{Al}_{2} \mathrm{O}_{3}$ ultrafine particles were selected due to their high chemical stability to $\mathrm{Fe}$ and high specific gravity. In particular, it was reported that the wetting angle $\theta$ between $\mathrm{Al}_{2} \mathrm{O}_{3}$ and molten iron alloy is less than $50^{\circ}$, even at high temperatures and in many different types of atmospheres. ${ }^{10}$

\subsection{Specimens preparation}

A weighed quantity $(10 \mathrm{~kg})$ of the austenitic stainless steel was melted in an induction furnace. In the first experiment $20 \mathrm{~g}$ of the ultrafine $\mathrm{Al}_{2} \mathrm{O}_{3}$ particles were wrapped in an $\mathrm{Al}$ foil and put into the ingot and the molten metal was poured over it into the same ingot. In the second experiment a mixture of $24 \mathrm{~g}$ of $\mathrm{Al}_{2} \mathrm{O}_{3}$ and $2.4 \mathrm{~g}$ of dry glue was prepared. The mixture was then filled in the steel tube and flooded with paraffin. The tube was inserted into the molten metal and when melted, the molten metal was poured into the ingot.
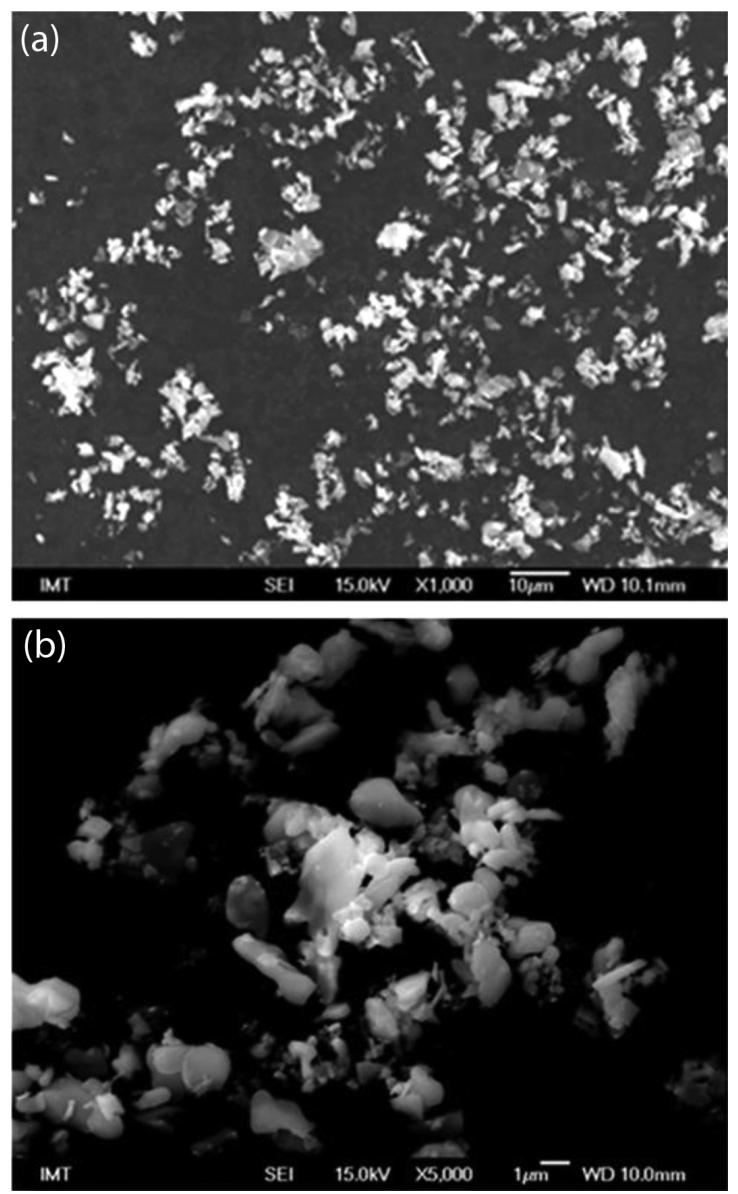

Figure 1: SEM image of $\mathrm{Al}_{2} \mathrm{O}_{3}$ ultrafine particles at various magnifications

Slika 1: SEM-posnetek ultrafinih delcev $\mathrm{Al}_{2} \mathrm{O}_{3}$ pri različnih povečavah

\subsection{Characterization}

The microstructural changes and the dispersion of the ceramic particles in the steel matrix were observed and analysed using light microscopy (LM), scanning electron microscopy (SEM) and auger electron spectroscopy (AES). Samples for the microstructure analysis were taken from the bottom, middle and top portions of the cast piece. Metallographic samples were prepared by grinding, polishing, followed by chemical etching and analysed to reveal the particle distribution. Samples for Auger electron spectroscopy were prepared by grinding and polishing the surface. These samples were attached to the bracket, placed in an experimental container-airlock, pumped to UHV and transferred into an analytical container. The surface of the sample was ion etched and analysed to determine the elemental composition in the surface region of the sample.

\section{RESULTS AND DISCUSSION}

Figure 2 shows a LM micrograph of the microstructure of pure austenitic stainless steel with a distinctive 
two-phase microstructure of austenite and $\delta$-ferrites. A LM micrograph of the microstructure and ultrafine particles' distribution of the sample produced by the casting process of the austenitic stainless steel poured over the $\mathrm{Al}_{2} \mathrm{O}_{3}$ ultrafine particles is shown in Figure 3.

As shown in Figure 3, the microstructure of the austenitic stainless steel is modified after the addition of $\mathrm{Al}_{2} \mathrm{O}_{3}$ ultrafine particles, being incorporated into the metal matrix. However, the distribution of $\mathrm{Al}_{2} \mathrm{O}_{3}$ particles is non-homogeneous and concentrated in a certain area.

In Figure 4 the particle distribution of the sample taken from the second experiment, where the steel tube filled with $\mathrm{Al}_{2} \mathrm{O}_{3}$ particles was inserted into the melt is shown. As in the case of the first experiment, with the molten steel being poured over the $\mathrm{Al}_{2} \mathrm{O}_{3}$ ultrafine particles, the distribution of the particles is non-uniform and has a high degree of agglomeration (Figure 4). However, the degree of particles is lower when inserting the particles-filled steel tube into the molten metal.

From the SEM elemental analysis, shown in Figure $\mathbf{5}$, it was confirmed that the bright, small, spot-like feat-

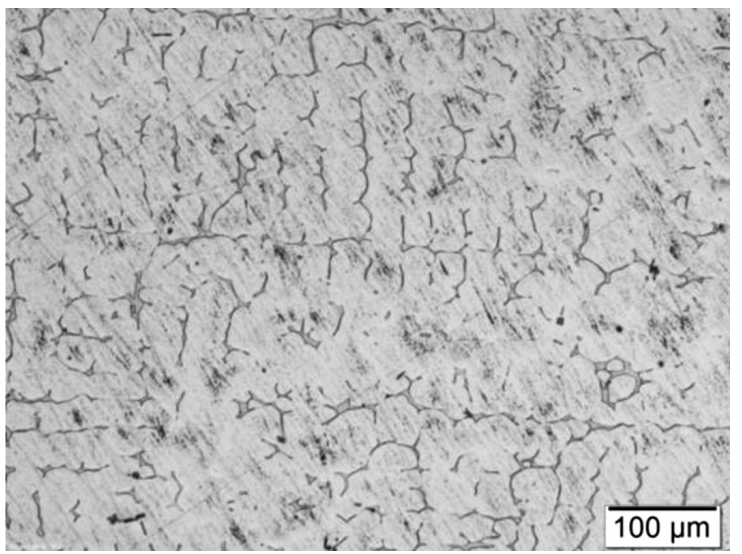

Figure 2: Cast microstructure of austenitic stainless steel with $6 \%$ of $\delta$-ferrite

Slika 2: Lita mikrostruktura avstenitnega nerjavnega jekla s $6 \% \delta$-ferita

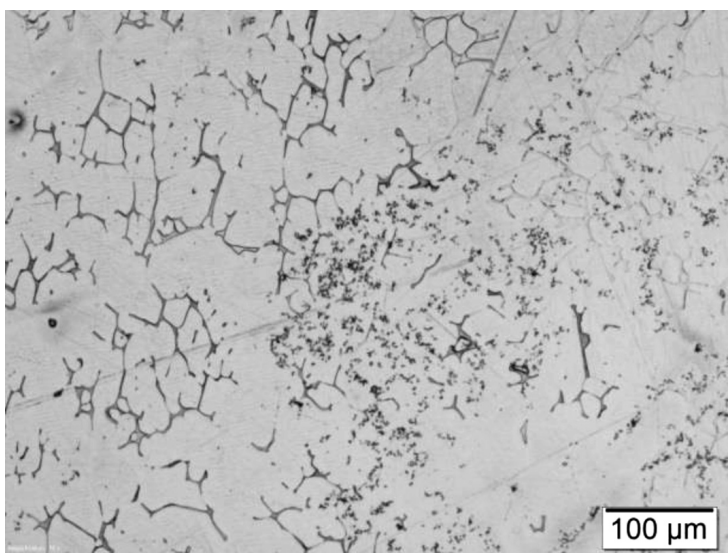

Figure 3: Cast microstructure of austenitic stainless steel with $6 \%$ of $\delta$-ferrite and $\mathrm{Al}_{2} \mathrm{O}_{3}$ ultrafine particles

Slika 3: Lita mikrostruktura avstenitnega nerjavnega jekla s $6 \% \delta$-ferita in $\mathrm{Al}_{2} \mathrm{O}_{3}$ ultrafinimi delci

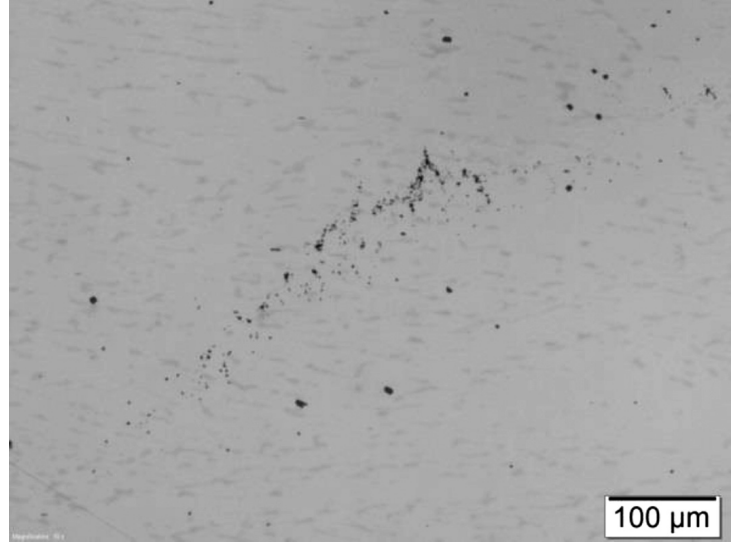

Figure 4: Cast microstructure of austenitic stainless steel with $\mathrm{Al}_{2} \mathrm{O}_{3}$ ultrafine particles inserted into the melt (experiment 2)

Slika 4: Lita mikrostruktura avstenitnega nerjavnega jekla $\mathrm{z} \mathrm{Al}_{2} \mathrm{O}_{3}$ ultrafinimi delci, vstavljenimi v talino (preizkus 2)

ures represent the $\mathrm{Al}_{2} \mathrm{O}_{3}$ ultrafine particles that are nonuniformly distributed in the steel matrix.

In Figure 6 the AES spectrum of the $\mathrm{Al}_{2} \mathrm{O}_{3}$ ultrafine particles in the cast microstructure of austenitic stainless steel is shown. The spectra of particles (P1 and P2) showing only $\mathrm{O}$ and $\mathrm{Al}$ peaks confirm the successful introduction of $\mathrm{Al}_{2} \mathrm{O}_{3}$ ultrafine particles into the steel matrix (P3) without any intermetallic reaction taking place.

\section{CONCLUSIONS}

Steel matrix composites with non-uniformly dispersed $\mathrm{Al}_{2} \mathrm{O}_{3}$ ultrafine particles were produced by a conventional melting and casting method. The purpose of this investigation was to determine the methodology and analysing techniques suitable for the analysis and identi-
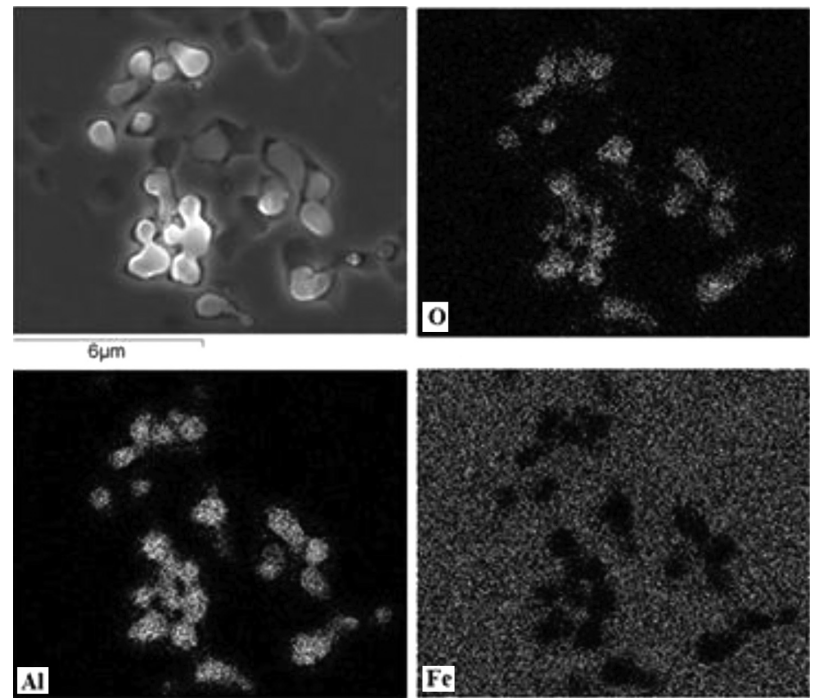

Figure 5: SEM elemental analysis of $\mathrm{Al}_{2} \mathrm{O}_{3}$ ultrafine particles in the cast microstructure of austenitic stainless steel

Slika 5: SEM-posnetek elementne analize $\mathrm{Al}_{2} \mathrm{O}_{3}$ ultrafinih delcev v liti mikrostrukturi avstenitnega nerjavnega jekla 

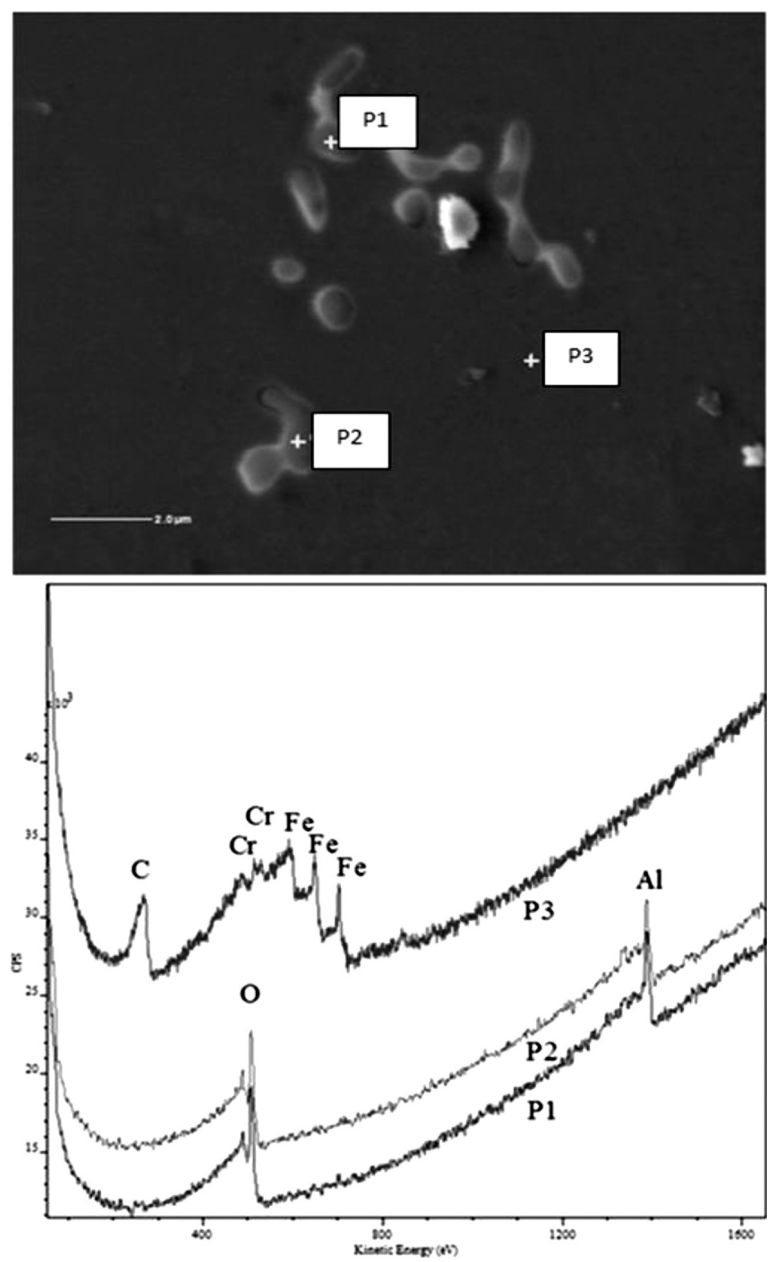

Figure 6: AES spectrum of the $\mathrm{Al}_{2} \mathrm{O}_{3}$ ultrafine particles in the cast microstructure of austenitic stainless steel

Slika 6: AES-spekter analize $\mathrm{Al}_{2} \mathrm{O}_{3}$ ultrafinih delcev v liti mikrostrukturi avstenitnega nerjavnega jekla

fication of ultrafine particles incorporated in the steel matrix.

The microstructural changes and the dispersion of the $\mathrm{Al}_{2} \mathrm{O}_{3}$ ultrafine particles in the steel matrix were observed and analysed by light microscopy (LM), scanning electron microscopy (SEM) and auger electron spectroscopy (AES). This work clearly shows that for a proper analysis and identification of the successful nano-particles' incorporation, different analysing techniques need to be used and combined.

Based on the experimental results the dispersion of the $\mathrm{Al}_{2} \mathrm{O}_{3}$ ultrafine particles in the steel matrix is nonhomogeneous and concentrated in certain areas.
In order to be able to obtain a homogeneous distribution of reinforcements in the metal matrices the following factors need to be understood and taken into consideration for future work:

- particle density, size, shape and volume fraction will influence the reinforcement settling rate,

- surface properties of the particles will affect the wetting with molten metal,

- rheological behaviour is influenced by the reaction of the particles with the melt and each other,

- in general, the reinforcement particles occupy interdendritic or between secondary dendrite arm spacings, while the particle distribution is also metalmatrix dependent.

\section{REFERENCES}

${ }^{1}$ Y. Q. Liu, H. T. Cong, W. Wang, C. H. Sun, H. M. Cheng, AlN nanoparticle-reinforced nanocrystalline Al matrix composites: Fabrication and mechanical properties. Met.Sic.Eng.A, 505 (2009), 151-156, doi:10.1016/j.msea.2008.12.045

${ }^{2}$ C. S. Goh, J. Wei, L. C. Lee, M. Gupta, Ductility improvement and fatigue studies in Mg-CNT nanocomposites. Comps. Sci. Tech. 68 (2008), 1432-1439, doi:10.1016/j.compscitech.2007.10.057

${ }^{3}$ Z. Razavi Hesabi, A. Simchi, S. M. Seyed Reihani, Structural evolution during mechanical milling of nanometric and micrometric $\mathrm{Al}_{2} \mathrm{O}_{3}$ reinforced Al matrix composites. Mater. Sci. Eng. A, 428, (2006), 159-168, doi: 10.1016/j.msea.2006.04.116

${ }^{4}$ J. Llorca, Fatigue of particle-and whisker reinforced metal-matrix composites. Prog.Mater.Sci., 47 (2002), 283-353, doi:10.1016/ S0079-6425(00)00006-2

${ }^{5}$ B. N. Chawla, Y. Shen, Mechanical Behavior of Particle Reinforced Metal Matrix Composites, Adv.Eng.Mater., 3 (2001) 6, 357-370, doi:10.1002/1527-2648(200106)3:6<357::AID-ADEM357>3.3.CO;2-9

${ }^{6}$ R. Casati, M. Vedani, Metal Matrix Composites Reinforced by Nano-Particles - A Review, Metals (Basel), 4 (2014) 1, 65-83, doi:10.3390/met4010065

${ }^{7}$ S. H. Lee, J. J. Park, S. M. Hong, B. S. Han, M. K. Lee, C. K. Rhee, Fabrication of cast carbon steel with ultrafine TiC particles. Trans Nonferrous Met. Soc. China (English Ed., 21 (2011), 54-57, doi:10.1016/S1003-6326(11)61060-1

${ }^{8}$ R. Konwar, A. B. Ahmed, Nanoparticle: an Overview of Preparation, Characterization and Application. Int. Res. J. Pharm., 4 (2013) 4, 47-57, doi:10.7897/2230-8407.04408

${ }^{9}$ C. Linsmeier, Auger electron spectroscopy. Vacuum, 45 (1994) 6-7, 673-690, doi:10.1016/0042-207X(94)90108-2

${ }^{10}$ S. Y. Cho, J. H. Lee, Anisotropy of wetting of molten Fe on $\mathrm{Al} 2 \mathrm{O} 3$ single crystal. Korean J. Mater. Res., 18 (2008) 1, 18-21, doi:10.3740/ MRSK.2008.18.1.018 